\title{
Membangun Pendidikan Karakter Santri Melalui Panca Jiwa Pondok Pesantren
}

\author{
Lisda Nurul Romdoni*, Elly Malihah \\ Universitas Pendidikan Indonesia, Indonesia \\ Jl. Dr. Setiabudi No. 229, Isola, Sukasari, Bandung, Jawa Barat, 40154 \\ Email: lisdaromdani@upi.edu
}

\begin{abstract}
The five souls of the Islamic boarding school are not just slogans, but the five souls are a character education that must be formed for students. To build the character of students there must be considered by a teacher or caregiver through the process of activities that are often done. The five souls are the five values that must be imbued and instilled by the students in building the character that is carried out in life. The atmosphere of the Islamic boarding school is very close to the values of life that build the character of students to have a spirit of sincerity, a spirit of simplicity, a spirit of independence, a spirit of brotherhood, and a spirit of freedom to prepare themselves to be virtuous, noble, and meaningful for a better life.
\end{abstract}

Keywords: Character Education, Five Souls, Islamic Boarding Schools

Abstrak: Panca jiwa pondok pesantren bukan hanya slogan saja, tetapi lima jiwa tersebut merupakan sebuah pendidikan karakter yang harus dibentuk untuk para santri. Untuk membangun karakter santri ada yang harus diperhatikan oleh seorang pengajar atau pengasuh melalui proses kegiatan yang sering dilakukan. Panca jiwa adalah lima nilai yang harus dijiwai dan ditanamkan oleh para santri dalam membangun karakter yang dijalankan dalam kehidupan. Suasana pondok pesantren sangat dekat dengan nilai-nilai kehidupan yang membangun karakter santri untuk mempunyai jiwa keikhlasan, jiwa kesederhanaan, jiwa kemandirian, jiwa persaudaraan, dan jiwa kebebasan untuk mempersiapkan diri menjadi individu berbudi luhur, berakhlak mulia, dan bermakna untuk kehidupan yang lebih baik.

Kata Kunci: Pendidikan Karakter, Panca Jiwa, Pondok Pesantren

Jurnal Pendidikan Agama Islam Al-Thariqah Vol. 5, No. 2, Juli - Desember 2020

Received: 11 April 2020; Accepted 21 June 2020; Published 06 December 2020

*Corresponding Author: lisdaromdani@upi.edu 


\section{PENDAHULUAN}

Pondok pesantren merupakan lembaga pendidikan Islam tertua dan sebagai budaya asli (indigenous) Indonesia serta memiliki akar kuat dalam masyarakat. Pondok pesantren mengalami transformasi yang fenomenal di Indonesia, hal ini terlihat bahwa pondok pesantren dan madrasah semakin terlibat dan memberikan kontribusi terhadap pendidikan Islam di Indonesia (Hamid, 2017: 130). Sebuah pondok pesantren memiliki 5 unsur atau komponen yang membedakan dengan lembaga pendidikan lainnya, yaitu adanya kiai, santri, masjid, asrama, dan pengajian kitab. Hal ini menandakan bahwa karakteristik pondok pesantren adalah lembaga pendidikan yang merupakan tempat santri mempelajari, memahami, mengamalkan ajaran agama Islam dengan diiringi akhlakul karimah dalam kehidupan, dengan bimbingan seorang guru yang dikenal sebagai kiai atau ustadz.

Di lingkungan pondok pesantren, kiai mempunyai peran sentral dimana hal tersebut terjadi karena tingkat keillmuan yang dimiliki seorang kiai sangatlah tinggi. Secara sosiologis peran kiai memiliki kelebihan dalam lingkungan masyarakat sebagai figur yang berpengaruh dan memungkinkan memberikan kontribusi untuk berbagai permasalahan masyarakat. Disini figur pemimpin atau kyai yang mempunyai jiwa keteladanan, maka dianggap sebagai modal berharga dalam menanamkan pembiasaan para santri melalui proses belajar mengajar (Muhaimin, 2002: 25). Oleh karena itu, peran kiai sangatlah penting dalam berbagai aspek kehidupan dari mulai spiritual, sosial, budaya, dan pendidikan. Namun saat ini, sudah banyak guru atau ustadz yang membantu peran tersebut dalam mengembangkan akhlak, ilmu dan pengetahuan santri di pondok pesantren. Hal ini menjadi perbedaan lain dari pondok pesantren yaitu lebih menekankan pada akhlak yang lebih dikenal sebagai karakter santri.
Kehidupan di pondok pesantren para santri tidak lepas dari bimbingan, pendidikan, dan pengawasan dari para kiai, dan ustadz. Pembelajaran berbasis pondok pesantren dari realitas alam dan kehidupan membangun karakter mandiri yang dikembangkan adalah disiplin dan bersungguh-sungguh, kemandirian dan kerja keras, religius, kebersamaan, peduli, kasih sayang, kesederhanaan, hormat, santun, tanggung jawab, jujur, dan ikhlas (Budiyanto, 2014: 108).

Tujuan pondok pesantren sendiri pada umumnya yaitu menciptakan santri yang mempunyai akhlakul karimah disertai dengan landasan hidup yang kuat berdasarkan Alquran dan Hadist. Sehingga jiwa seorang santri dapat dibentuk dan dikembangan dengan baik untuk menjadi Muslim yang patuh pada perintah Allah Swt, memiliki kebaikan dan karakter yang baik, dapat menunjukkan kepribadian yang kuat dan mandiri, dan memiliki kemampuan intelektual (Musqon, 2011: 156).

Seiring perkembangan jaman, lembaga pondok pesantren yang bersifat tradisional mulai mengalami pergeseran dengan perkembangan ilmu pengetahuan dan teknologi. Perkembangan teknologi, informasi dan komunikasi yang begitu pesat dan sulit dibendung, hal ini sangat berpengaruh terhadap pembiasaan dan perubahan karakter seorang santri (Hidayat, 2015: 129). Hari ini, banyak pondok pesantren modern yang terbuka bagi siapapun dan membuka diri dalam berbagai pelajaran umum. Sementara dari segi sarana, pondok pesantren modern sudah memiliki alat-alat elektronik untuk menunjang proses pendidikan seperti laptop, infocus, dan lainnya (Sulaiman, 2013: 135). Keadaan tersebut menyebabkan adanya sumber pembelajaran baru santri terhadap ilmu dan pengetahuan.

Dengan kata lain culture pesantren selalu mengalam proses perubahan, hal ini dilakukan oleh kyai terhadap lembagalembaga pesantren dewasa ini bukanlah 
merupakan pilihan alternatif yang bersilang jalan, melainkan merupakan akumulasi nilai-nilai kehidupan yang dialami pondok pesantren sepanjang sejarahnya, tanpa meninggalkan ruh (jiwa) atau tradisi-tradisi khasnya (Suradi, 2017: 273). Hal ini membuktikan bahwa lembaga pendidikan pondok pesantren memiliki fleksibilitas dalam menyesuaikan perkembangan ilmu pengetahuan dan teknologi.

Jiwa kepemimpinan yang diharapkan mengalami pergeseran yang menjadi persoalan dimana adanya kekhawatiran tidak adanya regenerasi dalam memimpin. Sehingga harus dibangun dari sistem pengelolaan pondok pesantren dengan baik. Mempertahankan culture pesantren yang berorientasi pada kesederhanaan dan keikhlasan seorang kyai dalam memberikan pengajaran untuk menciptakan generasi pemimpin yang baik diharapkan mampu memberikan pendidikan yang efektif dalam membentuk karakter santri di tengahtengah perkembangan zaman yang semakin kompleks. Hal itu bisa dilakukan dengan upaya meningkatkan kualitas pesantren, dengan menginternalisasikan pendidikan karakter didalamnya.

Pada dasarnya hakekat pondok pesantren terletak pada isi dan ruh (jiwa) nya, hal inilah yang membekali santri kelak dalam kehidupan di masyarakat. Jiwa-jiwa santri dibangun dengan suasana kehidupan yang Islami penuh nilai-nilai perjuangan dan pengorbanan, bahkan dengan kehidupan yang diliputi oleh jiwa keikhlasan, jiwa kesederhanaan, jiwa kemandirian, jiwa ukhuwah Islamiyah dan jiwa kebebasan yang bertanggungjawab adalah pemandangan yang dapat disaksikan dan suasana yang dapat dirasakan langsung dalam kehidupan sehari-hari di pesantren (Ummah, 2017: 206). Jiwa-jiwa tersebut menurut Imam Zarkasyi (Musqon, 2011: 159) dapat disederhanakan menjadilima roh, Panca Jiwa, yaitu: Ketulusan (al-ikhlâs), Kesederhanaan (al-basâtah), Kemandirian (al-i'timad'ala-l-nafsi), Ikhwanul Muslimin (al-ukhuwah al-Islamiya), Kebebasan (alhuriyâh).

Penelitian yang dilakukan Tanszhil (2012) menunjukkan bahwa membangun sebuah karakter kemandirian serta kedisiplinan santri di lingkungan pondok pesantren dilaksanakan melalui metode pembiasaan, dan pemberian pelajaran atau nasihat, metode pahala dan sanksi, serta metode keteladanan dari para kyiai serta pengajarnya. Sehingga hasil yang didapatkan dalam membangun karakter kemandirian dan kedisiplinan tersebut dibuktikan dengan adanya perubahan sikap, dan perilaku santri. Kemudian hadirnya kemandirian santri dalam berfikir dan bertindak, kedisiplinan santri dalam mengelola waktu, serta lahirnya figur-figur panutan dalam lingkungan masyarakat, hal tersebut menunjukkan berhasilnya pembinaan pendidikan karakter yang berdasarkan pada pembiasaan yang dilakukan di pondok pesantren.

Penelitian serupa yang dilakukan Suradi (2017) menunjukkan bahwa menanamkan panca jiwa perlu dilakukan secara fleksibel dan seiring dengan tuntutan dan perkembangan zaman, namun hal ini tetap harus memberikan filter sehingga nilai-nilai yang terkandung dalam pondok pesantren itu tidak pudar dari ajaran Islam. Hal ini sejatinya, sebuah pondok pesantren harus tetap mempertahankan budaya dan ajaran yang telah menjadi ruh (jiwa) nya ditengahtengah arus perkembangan dunia.

Berdasarkan uraian diatas, membangun pendidikan karakter yang dibangun melalui panca jiwa merupakan cara yang dianggap efektif dalam rangka meningkatkan kualitas pendidikan pesantren, dan mendorong santri memiliki karakter panca jiwa sebagai ruh (jiwa) perubahan ke arah kemajuan bangsa. Seiring dengan harapan penerapan panca jiwa dapat membangun karakter santri di pondok pesantren di tengah-tengah perkembangan arus 
kemajuan teknologi yang pesat, dengan ini perlu diteliti lebih jauh bagaimana internalisasi nilai-nilai panca jiwa terhadap penanaman karakter santri di pondok pesantren terhadap dinamika keilmuan yang dapat mengahadapi kemajuan ilmu pengetahan dan teknologi.

\section{KONSEP TEORI}

Pada dasarnya pendidikan karakter merujuk kepada Undang-Undang Nomor 20 tahun 2003 tentang sistem pendidikan nasional, yang menyatakan bahwa sebuah pendidikan merupakan uasaha terencana untuk mewujudkan peserta didik mengembangkan potensi dirinya memiliki sprititual keagamaan, pengendalian diri, kecerdasan, kepribadian, akhlak mulia, serta keterampilan yang berguna bagi dirinya dan bangsa.

Konsep panca jiwa merupakan sebuah penanaman karakter santri dalam memahami makna akhlakul karimah dan kepribadian yang didukung dengan pengetahuan yang luas. Panca Jiwa pertama kali digagas oleh K.H Iman Zakarsyi pada tahun 1939, pondok pesantren Gontor. Dimana 5 jiwa tersebut terdiri; Jiwa keikhlasan yang menciptakan suasana kehidupan pondok yang harmonis, Jiwa kesederhanaan meliputi jiwa besar yang yang dapat membangun karakter yang kuat dalam sebuah perjuangan, Jiwa berdikari dalam kesanggupan menolong dirinya sendiri dalam segala kepentingannya, Jiwa ukhuwah islamiyah membangun persaudaraan yang dapat meningkatkan jiwa persatuan dalam kehidupan, dan Jiwa kebebasan yang bisa menanamkan masa depan dan memilih tujuan hidup atas dasar kemampuan yang dimilikinya.

Konsep teori pendidikan karakter tidak hanya mengajarkan sesuatu yang dianggap baik atau salah kepada anak, jauh dari itu pendidikan karakter merupakan sebuah habituasi tentang kebaikan sehingga anak memiliki pemahaman, dan kemampuan dalam menjalankan kehidupan yang baik.
Pendidikan karakter yang berlandaskan Islam, merupakan pendidikan yang dibangun dari aspek epistimologi yang membuktikan bahwa sumber yang menentukan karakter seseorang tidak hanya berlandaskan akal semata, jauh dari itu melibatkan Allah SWT. dalam setiap kehidupannya (Agung, 2018: 52).

Oleh karena itu proses pendidikan karakter membutuhkan hubungan yang holistic dapat menghubungkan berbagai dimensi moral kehidupan sebagai dasar terbentuknya generasi yang mandiri. Demikian penelitian yang dilakukan Muminah (2015: 100) bahwa aspek panca jiwa sangatlah mendorong program pendidikan karakter yang memiliki relevansinya dengan keunggulan kepemimpinan, akhlak mulia, serta pengembangan lingkungan pendidikan yang lebih optimis.

\section{METODE PENELITIAN}

Pada penelitian ini berdasarkan (library research) atau penelitian dengan studi pustaka, yaitu pengumpulan data dan informasi dari jurnal ilmiah dan buku serta hasil penelitian. Dalam riset pustaka, menurut Zed (2004: 1) yaitu sebuah penelusuran atau penelitian yang memanfaatkan sumber kepustakaan untuk memperoleh sebuah data dalam penelitiannya. Demikian, sebuah riset dengan metode studi pustaka membatasi kegiatannya pada bahan koleksi data dari kepustakaan saja tanpa memerlukan untuk penelitian riset lapangan.

Data yang didapatkan kemudian dianalisis menggunakan pendekatan teoritis ilmiah (bedah pustaka) dengan menggabungkan beberapa pandangan tentang pendidikan karakter di pondok pesantren dan pandangan penelitian tentang pendidikan karakter lainnya yang relevan. Hasil dari riset ini adalah menjelaskan bagaimana pendidikan karakter di pondok pesantren, dan membangun karakter santri melalui panca jiwa pondok pesantren. 


\section{HASIL DAN PEMBAHASAN}

Pendidikan pada dasarnya adalah suatu usaha sadar untuk mewujudkan suasana belajar dan proses pembelajaran yang bertujuan untuk mengembangkan kepribadian dan kecerdasan serta keterampilan peserta didik. Sedangkan karakter adalah sifat alami seseorang yang dapat merespon situasi secara dinamis yang dalam tindakannya bisa melalui perilaku. Demikian pendidikan karakter adalah pendidikan nilai atau value education yang dibangun sebagai pemahaman untuk menanamkan watak dan perilaku yang baik (Mulyasa: 2012).

Pendidikan karakter merupakan usaha sadar terencana untuk melaksanakan pola aturan perilaku yang dianggap baik. Pendidikan karakter tidak hanya dilaksanakan oleh santri, namun semua unsur pondok pesantren ikut melaksanakan pendidikan karakter. Aristoteles mendefinisikan karakter yang baik sebagai tingkah laku yang baik. Tingkah laku yang benar dalam hubungannya dengan orang lain dan juga dengan diri-sendiri. Hal ini juga dimaksudkan sebagai bekal santri di kemudian hari dan dalam kehidupan bermasyarakat kelak.

Sistem penanaman nilai-nilai pendidikan karakter santri melalui komponen atau pendekatan pengetahuan, kesadaran, kemauan, serta kemampuan untuk melaksanakan nilai-nilai pendidikan karakter tersebut. Pembentukan karakter dibangun pada santri yang memiliki kecenderungan untuk mengikuti atau meniru pola perilaku sekitarnya, hal ini sangat mudah nilai-nilai pendidikan karakter ini masuk ke dalam long system memory santri.

Pondok pesantren adalah lembaga pendidikan Islam yang menjadi sarana bagi para santri dalam mempelajari, memahami, menghayati, serta mengamalkan ajaran Islam dan menekankan akhlakul karimah dalam kehidupan sehari-hari. Ciri khas pondok pesantren bisa dilihat dari adanya hubungan yang akrab antar santri dan guru, ciri lainnya yang paling khas yaitu adanya semangat gotong royong dalam melakukan suatu pekerjaan yang bermanfaat. Hal ini menjadi karakteristik pondok pesantren bahwa pendidikan di pondok pesantren tidak hanya mengajarkan berbagai cabang keilmuan yang terdapat dalam ajaran Islam, lebih dari itu para kiai, ustadz, dan pengasuh tentunya menyelipkan pembelajaran tentang kehidupan yang akan diimplementasikan langsung dalam kehidupannya kelak, mulai dari kesederhanaan, adab berpakaian, adab makan dan minum, adab tidur, adab pergaulan dan lainnya (Sumardi, 2012: 284).

Pola pendidikan yang diterapkan di pondok pesantren sangat beragam, hal ini bergantung pada target, kurikulum, metode, sistem manajemen pondok pesantren. Otonomi dalam pengelolaan Pondok Pesantren pun dipegang oleh Kiai dalam mengelola santri sesuai dengan evaluasi yang dilakukan selama proses pembelajaran (Sumardi, 2012: 283). Namun dibalik itu, fungsi dan tujuan pendidikan di pondok pesantren tidak lain yakni mendidik para santri untuk menjadi pribadi yang mempunyai akhlakul karimah berdasarkan Alquran dan Hadist.

Keberhasilan pendidikan karakter di pondok pesantren dapat dilihat dari beberapa faktor, pertama adanya peran sentral dari kiai yang memiliki figure sehingga santri bisa meneladani setiap perilaku kiai. Penelitian yang dilakukan Masrur (2017: 272) menunjukkan model kepemimpinan kyai merupakan tokoh yang tidak hanya dilihat oleh santri, tetapi kepemimpinan kyai juga dilihat oleh masyarakat sebagai tokoh yang ahli dalam bidang agama, sehingga dipandang dan dipercaya mampu memberikan solusi setiap permasalahan yang ada di masyarakat. Dengan demikian, pendidikan karakter yang dibangun atas dasar keteladanan, akan menghasilkan generasi muda yang mempunyai jiwa yang 
semangat, kerja keras, ikhlas, disiplin, dan mandiri sesuai dengan harapan bangsa.

Kedua, proses interaksi antara guru dan pengajar yang harmonis, penelitian yang dilakukan Zuhriy (2011: 306) bahwa peran guru atau pengasuh sangat penting dalam pendidikan karakter santri. Guru atau pengasuh menasihati dan membimbing, santri mengikutinya sebagai bentuk ketaatan pada sosok yang dikagumi. Selain itu, agar pelaksanaan seluruh aktivitas pondok berjalan sebagaimana yang diharapkan oleh pengasuh, maka perlu aturan santri ditegakkan. Dengan begitu proses penanaman karakter yang disinari oleh ajaran-ajaran kitab yang dipelajari serta teladan dari Kiai bisa dijalankan efektif.

Pondok pesantren memiliki pola hidup yang dikenal dengan Panca Jiwa. Artinya 5 jiwa yang harus ditanamkan dalam jiwa santri dan di aplikasikan dalam proses pendidikan di pondok pesantren, serta sebagai pembentukan karakter dan kepribadian santri dalam kehidupannya. Panca jiwa pondok pesantren merupakan nilai-nilai yang menjadi fokus dalam mengembangkan dan membangun potensi santri dalam membentuk softskill santri sebagai tujuan membentuk manusia yang beriman dan bertakwa, dan siap dalam menjalani kehidupan yang akan datang, serta diharapkan dapat menjadi generasi muda dalam membangun bangsa dan Negara kedepan (Asrori, 2017: 25).

Imam Zarkasyi (dalam Masqon. 2011, 159) panca jiwa tersebut dapat dijelaskan sebagai berikut; pertama, jiwa keikhlasan adalah prinsip yang ditanamkan dalam jiwa santri sebagai bentuk semangat untuk mengikuti semua kegiatan pondok pesantren. Sepi ing pamirih sebagai semboyan yang memberikan arti bahwa melakukan semua kegiatan pondok pesantren didorongan dengan keinginan dari hati, dan tidak didorong oleh keinginan lain (Suradi, 2017: 278). Jiwa ini begitupun harus di tanamkan oleh seluruh unsur pondok pesantren. Seorang
Kyai yang mempunyai peran sentral, dan pengaruh yang besar pun harus mempunyai jiwa keikhlasan dalam mengajarkan ilmu. Berikut ustadz, guru, dan pengelola manajemen pun harus berlaku demikian. Demikian suasana yang dirasakan antar unsur pondok pesantren akan berjalan dengan harmonis.

Jiwa ikhlas merupakan suatu hal yang mudah diucapkan tetapi tidak mudah untuk ditanamkan dalam hati. Sejak pertama kali anak masuk pondok pesantren dan dirinya telah resmi menjadi santri pondok, maka disitulah jiwa keikhlasan harus ditanamkan dengan sebaik-baiknya. Jiwa ikhlas tidak hanya dalam belajar dan mencari ilmu, tetapi ikhlas harus ditanamkan dalam setiap perbuatan termasuk melaksanakan ibadah, membantu orang lain, dan ikhlas berbuat kebaikan. Oleh karena itu, Ikhlas sangat penting untuk melihat sejauhmana para santri melakukan semua kegiatan yang sudah ditetapkan dengan jiwa yang lapang, hanya karena Allah semata (Ummah, 2017: 210) Jiwa keihlasan itu yang belum sepenuhnya diterapkan oleh para santri di pondok pesantren.

Dalam penelitian Dermawan (2016: 239) menunjukkan sikap ikhlas seorang santri memberikan kesadaran bahwa apapun yang diberikan dan diperintahkan pondok pesantren merupakan kebaikan. Hal ini diyakini santri sebagai pandangan bahwa ikhlas merupakan bagian dari ibadah. Penelitian Nujhan (2019: 103) juga menunjukkan bahwa dengan adanya jiwa keikhlasan ini santri dan guru serta semua unsur pondok pesantren bekerja keras serta bekerjasama saling mendukung satu sama lain untuk kemajuan pondok pesantren karena Allah SWT. Jiwa keikhlasan yang terdapat pada panca jiwa pondok pesantren menjadi penguatan karakter yang dimulai dari lingkungan terdekat, hal ini menjadi habituasi yang akan membangun karakter individu selaras dengan nilai-nilai karakter (Puspitasari, 2016: 49). 
Kedua, jiwa kesederhanaan menunjukkan kehidupan santri yang sederhana. Kesederhanaan sebagai perilaku yang positive dalam situasi kehidupan bahwa seseorang harus hidup berdasarkan pada kebutuhan dasar, bukan atas permintaan. Dengan hal ini setiap kesederhanaan santri dapat menumbuhkan kekuataan, keberanian, ketababahan, kesanggupoan, dan control diri dalam menghadapi perjuangan hidup (Masqon, 2011: 159). Jiwa kesederhanaan seorang santri diartikan bukan untuk hidup seperti tidak membutuhkan apaapa, tetapi kesederhanaan disini merupakan perilaku hidup yang biasabiasa saja, tidak berlebihan maupun bermegah-megahan.

Jiwa kesederhanaan dimulai dengan melalui cara hidup mereka sehari-hari di pondok pesantren dari mulai hal makan, tempat tidur, dan pakaian. Santri menunjukkan semua itu dengan sederhana dan tidak berlebih-lebihan. Oleh karena itu, dari jiwa ini tumbuhlah mental dan karakter santri yang kuat, sehingga santri diharapkan dapat menuju kesuksesan dan kebahagiaan dalam menjalani kehidupan, terutama di era globalisasi yang sangat kompleks dan penuh tantangan (Alhamudin, 2018: 59). Perilaku seperti itulah yang menjadikan santri memiliki kesederhanaan sebagai tombak kesuksesan yang akan di raih dikemudian hari.

Jika kita perhatikan, hari ini banyak pondok pesantren modern maupun tradisional yang sudah memiliki banyak sarana dan prasarana yang megah, namun hal ini ajaran yang dibelajarkan pada santri adalah kesederhanaan atas kemegahan yang dia jalani. Dan tidak jarang, santri yang berasal dari keluarga yang mampu ketika dia berada di pondok, maka harus menerapkan jiwa kesederhanaannya sebagai bekal di kehidupan masyarakat kelak. Menurut Ummah (2017: 211) contoh dari jiwa kesederhanaan dari uraian diatas, yaitu ketika pondok pesantren menetapkan berapa jumlah baju yang harus dibawa, sampai uang yang harus dipegang akan mendapatkan pantauan dari ustadz. Hal ini lah yang menjadikan jiwa kesederhanan yang membangun karakter santri untuk tetap mempunyai semangat, dan tanggung jawab dalam jiwanya.

Ketiga, jiwa kemandirian seorang santri adalah dimana setiap santri tidak bergantung pada orang lain dengan kata lain setiap santri harus bisa melakukan setiap kegiatan sesuai tanggung jawabnya. Pondok pesantren sendiri merupakan lembaga pendidikan yang bisa dikatakan berhasil menjadikan kemandirian sebagai sikap yang wajib dimiliki setiap santri tanpa adanya ketergantungan dengan orang lain (Masqon, 2011: 159). Jiwa kesederhanaan juga diartikan sebagai kesanggupan setiap santri dalam menolong diri sendiri atas semua kegiatan yang dijalani dalam kehidupannya.

Jiwa kemandirian bisa disebut juga sebagai jiwa berdikari yang bukan berarti dipahami menolak atau enggan diberi bantuan, namun hal ini menjadi pola pendidikan dimana santri dituntut untuk bertanggung jawab dan memenuhi kebutuhannya sendiri. Dalam penelitian Alhamuddin (2018: 59) menunjukkan pola pendidikan tersebut meliputi keperluannya sendiri, seperti mencuci pakaian, kasur untuk tempat tidur, kegiatan dan aktivitas yang disukainya, hingga mampu mengatur anggaran biaya belanja dan biaya sehari-hari di pondok pesantrennya. Praktek semacam ini menjadi bekal yang berguna bagi setiap santri ketika sudah menjalani kehidupan di masyarakat.

Menurut Darmawan (2016: 240) jiwa kemandirian ini menunjukkan bahwa seorang santri dapat mengurus dirinya sendiri, dalam arti tidak membutuhkan orang lain. Tetapi hal ini menjadi pendidikan hidup atas pilihan-pilihan hidup yang dilakukannya. Dengan demikian setiap santri harus membiasakan ikhlas menjalaninya dan menyadari bahwa semua ini sebagai 
bentuk pendidikan karakter mandiri yang akan membekalinya dikehidupan yang akan datang.

Keempat, jiwa ukhuwah islamiyah atau persaudaran Islam. Prinsip ini memberikan arti bagaimana membangun persahabatan yang kuat, saling menghormati, serta solidaritas yang tinggi. Kehidupan di pondok pesantren memberikan suasana yang mendukung santri untuk menciptakan suasana persatuan dan gotong royong, sehingga segala kesenangan bisa dirasakan bersama-sama. Penanaman jiwa persaudaraan terhadap santri akan terciptanya hubungan yang baik, hal ini demikian menjadikan para santri saling mengenal, memahami, dan menjadikan sesamanya sebagai saudara. Hal ini selaras dengan pendapat Nujhan (2019: 103) bahwa hidup ini akan terasa lebih indah manakali di antara sesama saling membantu dalam rangka meringankan beban sesamanya.

Jiwa persaudaraan ini bukan hanya diterapkan dan diamalkan dalam kehidupan ponok pesantren saja, tetapi lebih jauh dari itu memberikan pengaruh ke arah persatuan umat dalam masyarakat. Setelah seorang santri selesai mondok, akan kembali ke masyarakat dan menanamkan nilai-nilai persaudaraan yang akan dia bangun di tengah-tengah masyarakat dan kemajuan ilmu pengetahuan dan teknologi. Hal ini lah yang bisa disebut sebagai jembatan menuju terbangunnya jiwa ukhuwah islamiyah (Alhamuddin, 2019: 60).

Manusia merupakan makhluk sosial yang memiliki karakteristik untuk saling membutuhkan satu sama lain. Jiwa persaudaraan Islam ini dapat membangun karakter bersahabat dan komunikatif, artinya dengan semangat ukhuwah yang diterapkan dalam kehidupan pondok pesantren, akan membekalinya karakter bersahabat, dan juga cinta damai untuk mendorong dirinya untuk menjalin persaudaraan yang baik, dan saling menghormati terhadap sesamanya.
Kelima, jiwa kebebasan yang diberi arti sebagai sikap bebas santri dalam berpikir, bebas dalam berbuat, bebas dalam menentukan sesuatu, bebas dalam memilih jalan hidup, dan harus bebas dari segala pengaruh negatif (Alhamuddin. 2018: 60). Jiwa kebebasan ini diharapkan dapat menjadikan santri mempunyai jiwa yang besar serta optimis dalam menghadapi segala tantangan. Perlu dipahami, bahwa jiwa kebebasan ini bukan berarti santri harus mempunyai jiwa kebebasan yang sebebas-bebasnya, hal ini harus menjadi suatu kebebasan dalam garis dan batas disiplin dan semua kegiatan yang positif, serta dibarengi dengan sikap tanggung jawab.

Menurut Suradi (2017: 288) pondok pesantren berperan sebagai transfer of knowledge dan transfer of value, agar santri bisa mempersiapkan diri dalam menghadapi kehidupan sesungguhnya setelah kembali ke tengah masyarakat. Sehingga dalam penelitian yang dilakukan Dermawan (2016: 241) menunjukkan adanya jiwa kebebasan dalam kehidupan pondok pesantren dimana santri diberi kebebasan membuat karya-karya tulisan yang baik, berbahasa asing, karya akademik lainnya, lukisan atau gambar, dan yang paling penting santri harus diberi kebebasan dalam menentukan pilihan bakat, minat, dan keterampilannya. Demikian hal ini tetap mendapatkan perhatian dan arahan dari pondok pesantren.

Jiwa kebebasan ini tampak menjadi pembangunan karakter disiplin, kreatif, rasa ingin tahu, dan tanggung jawab santri. Demikian pondok pesantren menekankan santri untuk menjadi individu yang mampu menentukan garis kehidupannya. Mengembangkan potensi, serta dapat mengendalikan diri, kepribadian, kecerdasar, akhlak mulia, dan keterampilan santri. Dengan berkembangnya ilmu pengetahuan dan teknologi, kedepannya kehidupan seperti itu akan menguatkan setiap individu santri dalam mengorganisir segala 
sesuatunya serta mampu menjawab tantangan jaman yang semakin mengglobal (Dermawan, 2016: 242).

Nilai-nilai dan jiwa meliputi semua suasana kehidupan dalam pondok pesantren, dan diharapkan bisa membekali santri dalam kehidupan di masyarakat nanti. Dan perlu diketahui bahwa pondok pesantren adalah lembaga pendidikan yang mempertahankan tradisinya sebagai upaya menjaga ruh (jiwa) nya pondok pesantren. Ditengah arus kemajuan ilmu pengetahuan dan teknologi, pondok pesantren bisa menyesuaikan dengan situasi tersebut sesuai kebutuhan. Penelitian yang dilakukan Masqon (2011: 167) menunjukkan bahwa pondok pesantren selalu menerapkan komitmen untuk menjadikan pondok pesantren menjadi pusat pengembangan karakter yang didasarkan pada nilai-nilai ajaran Islam.

Berdasarkan pemaparan tujuan pendidikan pondok pesantren, nilai-nilai, dan jiwa yang ditanamankan kepada santri, dapat dipahami bahwa konsep pendidikan pondok pesantren sangat komprehensif. Pembelajaran yang diperoleh bisa dikatakan total, selain belajar agama para santri juga belajar kehidupan sesuai dengan ajaran agama. Perlu diketahui bahwa ilmu dan pengetahuan yang diajarkan di pondok pesantren hanya sebatas dasar agar bisa digunakan sebagai ilmu dasar santri dalam menggali lebih dalam ilmu-ilmu yang lain. Pondok pesantren senantiasa membekali para santri untuk menghadapi kehidupan di masyarakat, dan diharapkan dapat mengamalkan pembelajaran yang telah didapatkan.

\section{PENUTUP}

Berdasarkan hasil analisis di atas, maka dapat diambil dua kesimpulan. Pertama, pendidikan karakter di pondok pesantren sangatlah penting mengingat banyaknya pengaruh dari pesatnya kemajuan ilmu pengetahuan dan teknologi yang tidak bisa dibendung. Faktor utama keberhasilan ini adalah adanya figure kiai yang senantiasa menjadi tokoh yang menjadi suri tauladan para santri, dan hal ini tentunya harus didukung oleh semua unsur pondok pesantren, mengingat salah satu cara untuk membangun karakter di pondok pesantren yaitu melalui pembiasaan dalam kegiatan-kegiatan yang diselenggarakan oleh pondok pesantren.

Kedua, membangun karakter melalui panca jiwa pondok pesantren adalah proses pembentukan yang efektif, mengingat panca jiwa pondok pesantren adalah lima nilai jiwa yang harus ditanamkan setiap santri dalam menjalankan kehidupannya. Dengan jiwa keikhlasan, kesederhanaan, kemandirian, persaudaraan, dan kebebasan para santri akan menemukan kehidupan yang lebih penting dari pengetahuan, dengan mengingat bahwa etika yang baik merupakan nilai yang menjadi penghargaan pribadi yang harus diwujudkan dalam kehidupan masyarakat.[]

\section{DAFTAR RUJUKAN}

Hamid, Abdulloh. Pendidikan karakter Berbasis Pesantren: Pelajar dan Santri dalam era IT dan Cyber Culture. Imtiyaz, 2017.

Muhaimin, et al. Paradigma Pendidikan Islam: Upaya mengefektifkan pendidikan agama Islam di sekolah. Remaja Rosdakarya, 2001.

Mulyasa, Enco. "Manajemen pendidikan karakter." Jakarta: Bumi Aksara (2011): 165-189.

Zed, Mestika. Metode peneletian kepustakaan. Yayasan Obor Indonesia, 2004.

Agug, Agung. "Konsep Pendidikan Karakter Islami: Kajian Epistimologis" Al-Tarbawi AlHaditsah: Jurnal Pendidikan Islam. 3.2 (2018).

Alhamuddin, Alhamuddin, and Fahmi Fatwa Rosyadi Satria Hamdani. "Hidden Curriculum: Polarisasi Pesantren dalam Upaya Membentuk 
Kesalehan Individu Dan Sosial." $A L$ Murabbi: Jurnal Studi Kependidikan dan Keislaman 5.1 (2018): 50-65.

Asrori, Muhamad Abdul Roziq. "Perwujudan nilai-nilai strategis revolusi mental pendidikan pada kearifan lokal pesantren." Jurnal Civics: Media Kajian Kewarganegaraan 14.1 (2017): 2332.

Budiyanto, Mangun, and Imam Machali. "Pembentukan Karakter Mandiri Melalui Pendidikan Agriculture Di Pondok Pesantren Islamic Studies Center Aswaja Lintang Songo Piyungan Bantul Yogyakarta." Jurnal Pendidikan Karakter 2 (2014).

Dermawan, Andy. "Internalisasi Core Values Panca Jiwa Pondok Sebagai Budaya Organisasi (Studi Di Pesantren Putri Al-mawaddah, Coper, Ponorogo)." Jurnal MD 2.2 (2016).

Hidayat, Nur. "Implementasi Pendidikan Karakter Melalui Pembiasaan Di Pondok Pesantren Pabelan." Jurnal Pendidikan Sekolah Dasar Ahmad Dahlan 2.1 (2015): 95-106.

Masqon, Dihyatun. "Dynamic of Pondok Pesantren as Indegenous Islamic Education Centre In Indonesia." Tsaqafah 7.1 (2011): 155-168.

Mu'minah, Najwa. "Character Building Dalam Konsep Pendidikan Imam Zarkasyi Ditinjau Dari Filsafat Moral Ibnu Miskawaih." Jurnal Filsafat 25.1 (2015): 100-133.

Masrur, Mohammad. "Figur Kyai dan Pendidikan Karakter di Pondok Pesantren." Tarbawiyah Jurnal Ilmiah Pendidikan 1.01 (2018): 272282.

Nujhan, M. Rifai. "Makna Simbol Panca Jiwa (Analisis Semiotika Roland Barthes)." Jurnal Mediakita: Jurnal Komunikasi dan Penyiaran Islam 3.1 (2019).

Puspitasari, Euis. "Pendekatan Pendidikan Karakter." Edueksos: Jurnal
Pendidikan Sosial \& Ekonomi 3.2 (2016).

Sulaiman, Deded. "Manajemen Pendidikan Pesantren Modern dalam Pembentukan Karakter Anak: Studi Kasus pada Pondok Pesantren Modern Diniyyah Pasia Kabupaten Agam." Al-Fikrah: Jurnal Manajemen Pendidikan 1.2 (2016): 133-140.

Sumardi, Kamin. "Potret Pendidikan Karakter di Pondok Pesantren Salafiah." Jurnal Pendidikan Karakter 3 (2012).

Suradi, A. "Transformasi Pondok Pesantren (Analisis Dampak Transformasi Sistem Pendidikan Terhadap Penanaman Panca Jiwa Pondok Pesantren Kepada Santri di Provinsi Bengkulu)." Tadris: Jurnal Pendidikan Islam 12.2 (2017): 272297.

Tanshzil, Sri Wahyuni. "Model pembinaan pendidikan karakter pada lingkungan pondok pesantren dalam membangun kemandirian dan disiplin santri (Sebuah kajian pengembangan pendidikan kewarganegaraan)." penelitianpendidikan 305 (2012).

Ummah, Fiena Saadatul. "Panca Jiwa Pondok Pesantren: Sebuah Analisis Kritis." Joies: Journal of Islamic Education Studies 2.2 (2017): 18-30.

Zuhriy, M. Syaifuddien. "Budaya Pesantren Dan Pendidikan Karakter Pada Pondok Pesantren Salaf." Walisongo: Jurnal Penelitian Sosial Keagamaan 19.2 (2011): 287-310. 